\title{
HYPERCAPNIA AND HYPOXAEMIA DUE TO IMPAIRED VENOUS BLOOD DRAINING AND SIGNIFICANT IMPROVEMENT AFTER ENDOVASCULAR TREATMENT IN PATIENTS WITH CHRONIC CEREBROSPINAL VENOUS INSUFFICIENCY
}

\author{
Ivo Petrov, Lachezar Grozdinski, Svetlin Tsonev, Mariana lloska, Iveta Tasheva \\ University Hospital City Clinic, Sofia, Bulgaria
}

\begin{abstract}
Objectives: The aim of this prospective study was to investigate if venous blood coming from the brain and spinal cord in multiple sclerosis patients contains abnormal concentrations of oxygen and carbon dioxide and whether blood gas parameters normalise after successful endovascular angioplasty of abnormal veins.

Material and methods: In this study 178 multiple sclerosis patients with sonographically-proven chronic cerebrospinal venous insufficiency and 50 controls without multiple sclerosis and venous abnormalities were included. We obtained blood samples from the femoral, internal jugular, and azygous veins and measured: partial pressure of oxygen $\left(\mathrm{pO}_{2}\right)$, partial pressure of carbon dioxide $\left(\mathrm{pCO}_{2}\right)$, and oxygen saturation $\left(\mathrm{SatO}_{2}\right)$. In multiple sclerosis patients these blood gas parameters were evaluated before and after endovascular treatment for chronic cerebrospinal venous insufficiency.

Results: Blood samples obtained from the internal jugular veins in multiple sclerosis patients revealed significant hypercapnia and hypoxaemia. Blood from the azygous veins in these patients revealed hypercapnia, but not hypoxaemia. After endovascular treatment of the stenoses most of the abnormal blood gas parameters improved significantly: in the internal jugular veins - all parameters studied, while in the azygous vein - $\mathrm{pCO}_{2}$ and $\mathrm{pO}_{2}$ improved but $\mathrm{SatO}_{2}$ remained unchanged.

Conclusions: We demonstrated hypercapnia and hypoxaemia in the veins draining the brain and spinal cord in multiple sclerosis patients, and improvement of blood gas parameters after endovascular treatment for chronic cerebrospinal venous insufficiency. Nevertheless, it is unclear if this beneficial effect is long lasting and has any influence on the natural course of multiple sclerosis.
\end{abstract}

Key words: multiple sclerosis, chronic cerebrospinal venous insufficiency, hypercapnia, blood gas analysis, hypoxaemia.
ORIGINAL PAPER

Phlebological Review 2016; 24, 1: 20-24

DOl: $10.5114 /$ pr.2016.61534

Submitted: 12.10 .2015

Accepted: 13.06 .2016

\section{ADDRESS FOR CORRESPONDENCE}

Dr. Svetlin Tsonev

University Hospital City Clinic

Okolovrasten pat 127

1000 Sofia, Bulgaria

e-mail: svetmed@gmail.com

\section{INTRODUCTION}

It is well known that in many diseases, for example: acute mountain sickness, carbon dioxide intoxication, and chronic obstructive pulmonary disease, cerebral hypoxaemia is directly associated with cognitive disorders. It is also known that multiple sclerosis (MS) patients exhibit significant hypoperfusion of the brain [1-6]. However, it remains unclear whether cognitive disorders seen in MS patients are related to brain ischaemia, or rather to the neurodegeneration that is a hallmark of this neurological disease. Nonetheless, an observation that endovascular treatment of MS-associated extracranial venous abnormalities, so-called chronic cerebrospinal venous insufficiency (CCSVI), results in an improvement of some symptoms of MS, such as: chronic fatigue, dizziness, diplopia, dysarthria, and paraesthesia, may suggest that impairment of brain perfusion can be responsible for these symptoms of MS.

In some MS patients an improvement of clinical symptoms of MS is seen immediately after endovascular angioplasty of the narrowed veins. Given the rapid improvement of the clinical status of these patients, we suspected that this change was not due to a weakened autoimmunity, but rather due to the recovery of an easily changeable pathology, such as hypoxia and hypercapnia of the brain. A number of studies have revealed impaired functioning of the brain in the settings of hypoxia and hypercapnia [7-11]. Also, hypercapnia of the brain can result in disassembling of the blood-brain barrier $[12,13]$. 
Table 1. Gasometry of venous blood in the control group (no statistically significant differences between the veins, $p>0.05$ )

\begin{tabular}{lccc}
\hline Gasometric parameter & $\begin{array}{c}\text { Internal jugular vein } \\
\text { (mean value } \pm \text { standard deviation) }\end{array}$ & $\begin{array}{c}\text { Azygous vein } \\
\text { (mean value } \pm \text { standard deviation) }\end{array}$ & $\begin{array}{c}\text { Femoral vein } \\
\text { (mean value } \pm \text { standard deviation) }\end{array}$ \\
\hline $\mathrm{pCO}_{2}$ & $43.4 \pm 6.8 \mathrm{mmHg}$ & $43.1 \pm 6.7 \mathrm{mmHg}$ & $44.3 \pm 10.2 \mathrm{mmHg}$ \\
\hline $\mathrm{pO}_{2}$ & $39.7 \pm 8.6 \mathrm{mmHg}$ & $40.6 \pm 7.1 \mathrm{mmHg}$ & $40.0 \pm 9.8 \mathrm{mmHg}$ \\
\hline $\mathrm{SatO}_{2}$ & $61.3 \pm 12.0 \%$ & $72.0 \pm 6.9 \%$ & $74.1 \pm 14.0 \%$ \\
\hline
\end{tabular}

\section{AIM OF THE STUDY}

The aim of this study was to investigate if the venous blood coming from the brain and spinal cord indeed contains abnormally low concentration of oxygen and increased concentration of carbon dioxide in comparison with individuals without CCSVI, and whether these blood gas parameters improve after successful endovascular angioplasty of abnormal veins.

\section{MATERIAL AND METHODS}

A total of 178 patients with sonographically-proven CCSVI (using the so-called Zamboni's criteria [14]) and clinically defined MS (95 women and 83 men) were included after signing informed consent. The study design, protocol, and methods were approved by the Local Ethics Committee. The patients were aged $41.7 \pm 8.8$ years. They were self-referred and reported an MS diagnosis from their local neurologists. The mean value of the patients' EDSS (Extended Disability Status Scale) was 5.1. Mean duration of the disease was 8.6 years. The majority of patients (54\%) presented with relapsing-remitting clinical type of MS, while others were diagnosed with progressive forms of MS. The control group comprised 50 individuals ( 26 women and 24 men), aged $42.1 \pm 9.5$ years, who underwent other diagnostic or interventional procedures negative for CCSVI and MS. These patients did not present with signs of cardiovascular or respiratory failure. The controls, similarly to MS patients, also underwent sonographic scanning of veins of the neck using the Zamboni's criteria of CCSVI.

With the use of femoral access, in all patients from both groups, we introduced a diagnostic catheter into both internal jugular veins and the azygous vein. Through this catheter we drew blood samples from all the above-mentioned veins in the control group (from the internal jugular veins: from one side), whilst in MS patients the samples were drawn only from the veins that presented with at least 50\% stenosis (343 out of 356 internal jugular veins and 163 out of 178 azygous veins). We obtained such blood samples before the endovascular procedure and five minutes after patency of the vein had been successfully restored (using balloon angioplasty or stenting). In all patients (MS patients and controls) we also drew blood samples from the access site (femoral vein). We immediately performed gas analysis of blood samples and evaluated the following gasometric parameters: partial pressure of oxygen $\left(\mathrm{pO}_{2}\right)$, partial pressure of carbon dioxide $\left(\mathrm{pCO}_{2}\right)$ and oxygen saturation $\left(\mathrm{SatO}_{2}\right)$. The study was approved by the local ethical committee.

Statistical analysis was performed using Student's $t$ test to verify the hypothesis that concentrations of $\mathrm{O}_{2}$ and $\mathrm{CO}_{2}$ differed significantly between CCSVI patients and controls, and that these blood gas parameters changed significantly after endovascular treatment of pathological veins. The significance of the $p$ value was set at $<0.05$.

\section{RESULTS}

Sonographic assessment revealed the signs of CCSVI in all 178 MS patients, while none of the controls was diagnosed with CCSVI. Catheter venography demonstrated abnormalities in all assessed MS patients: in 165 patients $(92.7 \%)$ in both internal jugular veins, and in 13 patients $(7.3 \%)$ in one internal jugular vein. The majority of these abnormal veins (239 veins) presented with $50-80 \%$ stenosis, 104 internal jugular veins were found to be stenosed more than $80 \%$. In addition, we found 163 stenosed azygous veins $(91.6 \%)$ - there were 116 azygous veins with $50-80 \%$ stenosis and 47 veins stenosed more than $80 \%$.

Values of gasometric parameters of blood samples obtained from control individuals are presented in Table 1. All parameters $\left(\mathrm{pO}_{2}, \mathrm{pCO}_{2}\right.$ and $\left.\mathrm{SatO}_{2}\right)$ were within normal ranges and there were no statistically significant differences between blood samples drawn from the femoral, azygous, and internal jugular veins $(p<0.05)$. Similarly, gasometric parameters of blood samples drawn from the femoral veins in MS patients were normal, and there were no statistically significant differences between controls and MS patients (Table 2).

Table 2. A comparison of gasometry of venous blood from the femoral vein between the controls and MS patients (no statistically significant differences between the groups, $p>0.05$ )

\begin{tabular}{lcc}
\hline $\begin{array}{l}\text { Gasometric } \\
\text { parameter }\end{array}$ & $\begin{array}{c}\text { Control group: femoral vein } \\
\text { (mean value } \pm \text { standard } \\
\text { deviation) }\end{array}$ & $\begin{array}{c}\text { MS patients: femoral vein } \\
\text { (mean value } \pm \text { standard } \\
\text { deviation) }\end{array}$ \\
\hline $\mathrm{pCO}_{2}$ & $44.3 \pm 16.2 \mathrm{mmHg}$ & $45.4 \pm 6.6 \mathrm{mmHg}$ \\
\hline $\mathrm{pO}_{2}$ & $40.0 \pm 9.8 \mathrm{mmHg}$ & $40.5 \pm 8.3 \mathrm{mmHg}$ \\
\hline $\mathrm{SatO}_{2}$ & $74.1 \pm 14.0 \%$ & $72.6 \pm 12.7 \%$ \\
\hline
\end{tabular}


Conversely, blood samples taken from the internal jugular veins in MS patients revealed hypercapnia and hypoxaemia, with the values significantly different from those of the controls (Table 3). Blood samples taken from the azygous veins in MS patients revealed significant hypercapnia, but not hypoxaemia (Table 4). After endovascular treatment of the stenoses most of the abnormal blood gas parameters improved significantly; in the internal jugular veins - all parameters studied (Table 5), while in the azygous vein - $\mathrm{pCO}_{2}$ and $\mathrm{pO}_{2}$ improved, but $\mathrm{SatO}_{2}$ remained unchanged (Table 6).

\section{DISCUSSION}

For the first time Zamboni et al. demonstrated in a small pilot study that there is a significant relationship between the severity of CCSVI and hypoperfusion in the brain parenchyma. The authors comment that these preliminary findings should be confirmed in a larger cohort of MS patients to ensure that they generalise to the MS population as a whole. Reduced perfusion could contribute to the known mechanisms of virtual hypoxia in degenerated axons [15].

Table 3. A comparison of gasometry of venous blood from the internal jugular veins between the controls and MS patients (significance of differences between blood gas parameters in the control group and MS patients: ${ }^{*} p<0.05$; ${ }^{* *} p<0.001$ )

\begin{tabular}{lcccc}
\hline $\begin{array}{l}\text { Gasometric } \\
\text { parameter }\end{array}$ & $\begin{array}{c}\text { Control group: internal } \\
\text { jugular vein (mean value } \\
\pm \text { standard deviation) }\end{array}$ & $\begin{array}{c}\text { MS patients: all internal } \\
\text { jugular veins with stenoses } \\
\text { (mean value } \pm \text { standard } \\
\text { deviation) }\end{array}$ & $\begin{array}{c}\text { MS patients: internal jugular } \\
\text { veins with 50-80\% stenosis } \\
\text { (mean value } \pm \text { standard } \\
\text { deviation) }\end{array}$ & $\begin{array}{c}\text { MS patients: internal jugular } \\
\text { veins with }>80 \% \text { stenosis } \\
\text { (mean value } \pm \text { standard } \\
\text { deviation) }\end{array}$ \\
\hline number of assessed veins & 50 & 343 & 239 & 104 \\
\hline $\mathrm{pCO}_{2}$ & $43.4 \pm 6.8 \mathrm{mmHg}$ & $54.5 \pm 5.4 \mathrm{mmHg}^{* *}$ & $52.4 \pm 5.0 \mathrm{mmHg}^{* *}$ & $55.8 \pm 5.8 \mathrm{mmHg}^{* *}$ \\
\hline $\mathrm{pO}_{2}$ & $39.7 \pm 8.6 \mathrm{mmHg}$ & $34.0 \pm 4.1 \mathrm{mmHg}^{* *}$ & $32.0 \pm 3.9 \mathrm{mmHg}^{* *}$ & $35.0 \pm 4.5 \mathrm{mmHg}^{* *}$ \\
\hline $\mathrm{SatO}_{2}$ & $61.3 \pm 12.0 \%$ & $55.2 \pm 7.8 \% \%^{* *}$ & $51.4 \pm 7.1 \%$ ** & $57.9 \pm 8.6 \%^{*}$ \\
\hline
\end{tabular}

Table 4. A comparison of gasometry of venous blood from the azygous veins between the controls and MS patients (significance of differences between blood gas parameters in the control group and MS patients: ${ }^{*} p<0.001$ )

\begin{tabular}{lcccc}
\hline Gasometric parameter & $\begin{array}{c}\text { Control group: azygous } \\
\text { vein (mean value } \\
\pm \text { standard deviation) }\end{array}$ & $\begin{array}{c}\text { MS patients: all azygous } \\
\text { veins with stenoses (mean } \\
\text { value } \pm \text { standard stenosis }\end{array}$ & $\begin{array}{c}\text { MS patients: azygous veins } \\
\text { with 50-80\% stenosis (mean } \\
\text { value } \pm \text { standard stenosis }\end{array}$ & $\begin{array}{c}\text { MS patients: azygous veins } \\
\text { with }>80 \% \text { stenosis (mean } \\
\text { value } \pm \text { standard stenosis }\end{array}$ \\
\hline number of assessed veins & 50 & 163 & 116 & 47 \\
\hline $\mathrm{pCO}_{2}$ & $43.1 \pm 6.7 \mathrm{mmHg}$ & $48.6 \pm 4.7 \mathrm{mmHg}^{*}$ & $47.3 \pm 6.4 \mathrm{mmHg}^{*}$ & $48.6 \pm 4.7 \mathrm{mmHg}^{*}$ \\
\hline $\mathrm{pO}_{2}$ & $40.6 \pm 7.1 \mathrm{mmHg}$ & $40.3 \pm 8.5 \mathrm{mmHg}$ & $40.2 \pm 7.0 \mathrm{mmHg}$ & $40.4 \pm 8.5 \mathrm{mmHg}$ \\
\hline $\mathrm{SatO}_{2}$ & $72.0 \pm 6.9 \%$ & $71.8 \pm 9.5 \%$ & $71.6 \pm 10.7 \%$ & $71.9 \pm 9.5 \%$ \\
\hline
\end{tabular}

Table 5. A comparison of gasometry of venous blood drawn from the internal jugular veins in MS patients before and after endovascular treatment of the stenoses (significance of differences between blood gas parameters before and after endovascular treatment: $\left.{ }^{*} p<0.01 ;{ }^{* *} p<0.001\right)$

\begin{tabular}{|c|c|c|c|c|c|c|}
\hline $\begin{array}{l}\text { Gasometric parame- } \\
\text { ter (mean value } \\
\pm \text { standard stenosis) }\end{array}$ & $\begin{array}{l}\text { All internal } \\
\text { jugular veins with } \\
\text { stenoses - before } \\
\text { the treatment }\end{array}$ & $\begin{array}{l}\text { All internal } \\
\text { jugular veins with } \\
\text { stenoses - after } \\
\text { the treatment }\end{array}$ & $\begin{array}{l}\text { Internal jugular } \\
\text { veins with } \\
50-80 \% \text { stenosis } \\
\text { - before the } \\
\text { treatment }\end{array}$ & $\begin{array}{l}\text { Internal jugular } \\
\text { veins with } \\
50-80 \% \text { stenosis } \\
\text { - after the } \\
\text { treatment }\end{array}$ & $\begin{array}{l}\text { Internal jugular } \\
\text { veins with }>80 \% \\
\text { stenosis - before } \\
\text { the treatment }\end{array}$ & $\begin{array}{l}\text { Internal jugular } \\
\text { veins with > } 80 \% \\
\text { stenosis - after } \\
\text { the treatment }\end{array}$ \\
\hline number of assessed veins & 343 & 343 & 239 & 239 & 104 & 104 \\
\hline $\mathrm{pCO}_{2}$ & $54.5 \pm 5.4 \mathrm{mmHg}$ & $52.0 \pm 2.8 \mathrm{mmHg}^{* *}$ & $52.4 \pm 5.0 \mathrm{mmHg}$ & $50.2 \pm 4.0 \mathrm{mmHg}^{*}$ & $55.8 \pm 5.8 \mathrm{mmHg}$ & $54.0 \pm 2.8 \mathrm{mmHg}$ * \\
\hline $\mathrm{pO}_{2}$ & $34.0 \pm 4.1 \mathrm{mmHg}$ & $38.5 \pm 4.9 \mathrm{mmHg}^{* *}$ & $32.0 \pm 3.9 \mathrm{mmHg}$ & $35.7 \pm 4.8 \mathrm{mmHg}^{* *}$ & $35.0 \pm 4.5 \mathrm{mmHg}$ & $38.5 \pm 4.9 \mathrm{mmHg}^{* *}$ \\
\hline $\mathrm{SatO}_{2}$ & $55.2 \pm 7.8 \%$ & $63.0 \pm 1.4 \%$ ** & $51.4 \pm 7.1 \%$ & $61.2 \pm 8.0 \%$ * * & $57.9 \pm 8.6 \%$ & $63.0 \pm 1.4 \%$ ** \\
\hline
\end{tabular}


Table 6. A comparison of gasometry of venous blood drawn from azygous vein in MS patients before and after endovascular treatment of the stenoses (significance of differences between blood gas parameters before and after endovascular treatment: $\left.{ }^{*} p<0.05 ;{ }^{* *} p<0.001\right)$

\begin{tabular}{lcccccc}
\hline $\begin{array}{l}\text { Gasometric parame- } \\
\text { ter (mean value } \pm \\
\text { standard stenosis) }\end{array}$ & $\begin{array}{c}\text { All azygous veins } \\
\text { with stenoses } \\
\text { - before the } \\
\text { treatment }\end{array}$ & $\begin{array}{c}\text { All azygous veins } \\
\text { with steno- } \\
\text { ses - after the } \\
\text { treatment }\end{array}$ & $\begin{array}{c}\text { Azygous veins } \\
\text { with } 50-80 \% \\
\text { stenosis - before } \\
\text { the treatment }\end{array}$ & $\begin{array}{c}\text { Azygous veins } \\
\text { with } 50-80 \% \\
\text { stenosis - after } \\
\text { the treatment }\end{array}$ & $\begin{array}{c}\text { Azygous veins } \\
\text { with }>80 \% \\
\text { stenosis - before } \\
\text { the treatment }\end{array}$ & $\begin{array}{c}\text { Azygous veins } \\
\text { with }>80 \% \\
\text { stenosis - after } \\
\text { the treatment }\end{array}$ \\
\hline number of assessed veins & 163 & 163 & 116 & 116 & 47 & 47 \\
\hline $\mathrm{pCO}_{2}$ & $48.6 \pm 4.7 \mathrm{mmHg}$ & $43.3 \pm 7.4 \mathrm{mmHg}^{* *}$ & $47.3 \pm 6.4 \mathrm{mmHg}$ & $44.5 \pm 6.4 \mathrm{mmHg}^{* *}$ & $48.6 \pm 4.7 \mathrm{mmHg}$ & $43.3 \pm 7.4 \mathrm{mmHg}^{* *}$ \\
\hline $\mathrm{pO}_{2}$ & $40.3 \pm 4.1 \mathrm{mmHg}$ & $43.4 \pm 8.9 \mathrm{mmHg}^{* *}$ & $40.2 \pm 7.0 \mathrm{mmHg}$ & $39.5 \pm 5.8 \mathrm{mmHg}^{*}$ & $40.4 \pm 8.5 \mathrm{mmHg}$ & $44.3 \pm 9.9 \mathrm{mmHg}^{*}$ \\
\hline $\mathrm{SatO}_{2}$ & $71.8 \pm 6.9 \%$ & $71.1 \pm 12.4 \%$ & $71.6 \pm 10.7 \%$ & $69.2 \pm 10.1 \%$ & $71.9 \pm 9.5 \%$ & $71.9 \pm 12.4 \%$ \\
\hline
\end{tabular}

Another working group of Utriainen used magnetic resonance imaging (MRI) as an imaging method in MS patients and CCSVI. The authors analysed vascular structure and flow as well as brain iron content. They confirmed that in MS patients there is impairment both in major vessels and in the brain. Also in that study it was suggested that the presence of high iron content may indirectly indicate progression of existing vascular pathology [5].

In our study we demonstrated hypercapnia and hypoxaemia of venous blood draining the brain and spinal cord in MS patients, and improvement of these blood gas parameters after endovascular treatment of pathologically changed veins. Of note, MS patients and controls presented with the same blood gas parameters in the femoral veins, so the difference was probably primarily due to stenoses of the internal jugular and azygous veins.

A number of studies have demonstrated an association of CCSVI with MS $[1,6,7,16]$, and it was hypothesised that impaired cerebral venous drainage may lead to local venous hypertension and dysfunction of the bloodbrain barrier, which in turn may evoke autoimmune reaction and neurodegeneration [17]. Still, an association of CCSVI with MS was not confirmed by many authors, probably not only because of the different diagnostic protocols used, but primarily due to much a more complex relationship between CCSVI and MS than was initially believed [18].

We measured $\mathrm{pO}_{2}, \mathrm{pCO}_{2}$, and $\mathrm{SatO}_{2}$ in the internal jugular and azygous veins. Therefore, we cannot rule out the possibility that altered blood gas parameters did not reflect the actual hypercapnia and hypoxaemia of the central nervous system. It is also likely that local stasis of blood in abnormal extracranial veins could be responsible. Also, it was possible that hypercapnia and hypoxaemia in blood samples drawn from the internal jugular veins were partially caused by asymmetric venous outflow from the brain $[16,19,20]$. Still, the studies utilising perfusion MRI have shown that MS patients exhibit significant hypoperfusion of the brain [1-5]. Thus, it is reasonable to suggest that MS patients present with hypercapnia and hypoxaemia of the brain and spinal cord, which are at least partially caused by CCSVI, and that this pathological condition can be improved using an endovascular approach. It is unclear, however, if this beneficial effect is long lasting and has any influence on the natural course of MS. We suggest that future research should answer these questions.

The authors declare no conflict of interest.

\section{References}

1. Adhya S., Johnson G., Herbert J., Jaggi H., Babb J.S., Grossman R.I., Inglese M. Pattern of hemodynamic impairment in MS: dynamic susceptibility contrast perfusion MR imaging at 3.0 T. Neuroimage 2006; 33: 1029-1035.

2. Ge Y., Law M., Johnson G., Herbert J., Babb J.S., Mannon L.J., Grossman R.I. Dynamic susceptibility contrast perfusion MR imaging of MS lesions: characterizing hemodynamic impairment and inflammatory activity. AJNR Am J Neuroradiol 2005; 26: 1539-1547.

3. Law M., Saindane A.M., Ge Y., Babb J.S., Johnson G., Mannon L.J., Herbert J., Grossman R.I. Microvascular abnormality in relapsing-remitting multiple sclerosis: perfusion MR imaging findings in normal-appearing white matter. Radiology 2004; 231 : 645-652.

4. Saindane A.M., Law M., Ge Y., Johnson G., Babb J.S., Grossman R.I. Correlation of diffusion tensor and dynamic perfusion MR imaging metrics in normal-appearing corpus callosum: support for primary hypoperfusion in multiple sclerosis. AJNR Am J Neuroradiol 2007; 28: 767-772.

5. Utriainen D., Trifan G., Sethi S., Elias S., Hewett J., Feng W., Haacke EM. Magnetic resonance imaging signatures of vascular pathology in multiple sclerosis. Neurol Res 2012; 34: 780-792.

6. Zivadinov R., Marr K., Cutter G., Ramanathan M., Benedict R.H., Kennedy C., Elfadil M., Yeh A.E., Reuther J., Brooks C., Hunt K., Andrews M., Carl E., Dwyer M.G., Hojnacki D., Weinstock-Guttman B. Prevalence, sensitivity, and specificity of chronic cerebrospinal venous insufficiency in MS. Neurology 2011; 77: 138-144.

7. Antonelli Incalzi R., Marra C., Giordano A., Calcagni M.L., Cappa A., Basso S., Pagliari G., Fuso L. Cognitive impairment in chronic obstructive pulmonary disease - a neuropsychological and SPECT study. J Neurol 2003; 250: 325-332. 
8. Douglas R.M., Ryu J., Kanaan A., Del Carmen Rivero M., Dugan L.L., Haddad G.G., Ali S.S. Neuronal death during combined intermittent hypoxia/hypercapnia is due to mitochondrial dysfunction. Am J Physiol Cell Physiol 2010; 298: C1594-1602.

9. Shim T.S., Lee J.H., Kim S.Y., Lim T.H., Kim S.J., Kim D.S., Kim W.D. Cerebral metabolic abnormalities in COPD patients detected by localized proton magnetic resonance spectroscopy. Chest 2001; 120: 1506-1513.

10. Varga A.W., Johnson G., Babb J.S., Herbert J., Grossman R.I., Inglese M. White matter hemodynamic abnormalities precede sub-cortical gray matter changes in MS. J Neurol Sci 2009; 282: 28-33.

11. Zamboni P., Galeotti R. The chronic cerebrospinal venous insufficiency syndrome. Phlebology 2010; 25: 269-279.

12. Johansson B., Nilsson B. The pathophysiology of the bloodbrain barrier dysfunction induced by severe hypercapnia and by epileptic brain activity. Acta Neuropathol 1977; 38: 153-158.

13. Zamboni P., Galeotti R., Menegatti E., Malagoni A.M., Tacconi G., Dall'Ara S., Bartolomei I., Salvi F. Chronic cerebrospinal venous insufficiency in patients with multiple sclerosis. J Neurol Neurosurg Psychiatry 2009; 80: 392-399.

14. Nicolaides A.N., Morovic S., Menegatti E., Viselner G., Zamboni P. Screening for chronic cerebrospinal venous insufficiency (CCSVI) using ultrasound: recommendations for a protocol. Funct Neurol 2011; 26: 229-248.

15. Zamboni P., Menegatti E., Weinstock-Guttman B., Dwyer M.G., Schirda C.V., Malagoni A.M., Hojnacki D., Kennedy C., Carl E., Bergsland N., Magnano C., Bartolomei I., Salvi F., Zivadinov R. Hypoperfusion of brain parenchyma is associated with the severity of chronic cerebrospinal venous insufficiency in patients with multiple sclerosis: a cross-sectional preliminary report. BMC Med 2011; 9: 22.

16. Beards S.C., Yule S., Kassner A., Jackson A. Anatomical variation of cerebral venous drainage: the theoretical effect on jugular bulb samples. Anaesthesia 1998; 53: 627-633.

17. Simka M. Blood brain barrier compromise with endothelial inflammation may lead to autoimmune loss of myelin during multiple sclerosis. Curr Neurovasc Res 2009; 6: 132-139.

18. Simka M., Ludyga T., Latacz P., Kazibudzki M., Majewski E., Zaniewski M. Chronic cerebrospinal venous insufficiency is unlikely to be a direct trigger of multiple sclerosis. Mult Scler Relat Disord 2013; 2: 334-339.

19. Metz C., Holzschuh M., Bein T., Woertgen C., Rothoerl R., Kallenbach B., Taeger K., Brawanski A. Monitoring of cerebral oxygen metabolism in the jugular bulb: reliability of unilateral measurements in severe head injury. J Cerebral Blood Flow Metab 1998; 18: 332-343.

20. Simka M., Ludyga T., Janas P., Kazibudzki M., Latacz P. Endothelin-1 concentrations in the internal jugular and azygous veins in multiple sclerosis patients: the results of a pilot study. Phlebol Rev 2014; 22: 18-23. 